\title{
An Indigenous Approach To Māori Healing With Papatūānuku
}

\author{
Charlotte Mildon
}

\author{
Te OOMAI REIA ROMIROMI PRACTITIONER
}

\begin{abstract}
This paper reveals the significance of the female role in the healing of mother nature (Papatūānuku) and all her progeny for Mãori living in Aotearoa New Zealand. I discuss how understanding the synchronisation of the male and female energies can balance the spiritual health, wellbeing, and healing of Māori and their whānau (families). My own whakapapa that traverses back to the beginnings of time informs my methodology which acknowledges the wider whannau concept and links with both the living and the nonliving ancestors of nature. These divine feminine descendants and spiritual guardians are identified as the essential foundation of traditional Māori healing. I examine the interconnectedness of Māori (ordinary, natural) people being a living consciousness with an innate ability to link in with the ancient mother energies of nature and all her progeny. The unconditional love of the ancient mother energies of nature are the spiritual source of healing for Māori and can be instrumental in balancing the natural order of the male and the female roles within the self, the whānau, and the wider whānau unit of mother nature.
\end{abstract}

\section{Waitara}

He whakaaturanga tā tēnei tuhinga i te tohu o te tūnga o te wahine i roto i ngā tumahu o Papatūānuku me ana uri katoa ki te Māori e noho nei i Aotearoa. Ka matapakihia e au mā te mātauranga mahitahitanga o te pūngao tāne me te pūngao wahine e whakarite te hauora wairua, te hauora me te tumahu o te Māori me ō rātau whānau. Ko tōku whakapapa e hoki nei ki te kore ki te tīmatanga o te wā te hua o taku tikanga mahi e whakaae ana ki te ariā whānau whānui ka whaiheretahi ki te hunga ora me te hunga mate o te ao tūroa. Ko ènei hekenga māreikura kaitiaki wairua e tohua ana ko te tūāpapa o te tikanga tumahu Māori. Ka arotakehia e au te whakahononga o te iwi Māori koia nei te koiora mauri ora mau momo ki te hono atu ki a pūngao tūroa me ōna hekenga katoa. Ko te tuku aroha herekore o ngā pūngao tūroa te pūtaketanga o te tumahu mō te Māori; te mea hai whakarite i te paparangi o te tikanga tāne tikanga wahine rō whaiaro, rō whānau me te whānau whānui o te ao tūroa.

Mildon, C. (2016). An Indigenous approach to Māori healing with Papatūānuku. Ata: Journal of Psychotherapy Aotearoa New Zealand, 20(1), 11-17. DOI:10.9791/ajpanz.2016.02 @ New Zealand Association of

Psychotherapists Inc. 
Keywords: romiromi; nature; Māori healing; Papatūānuku

\section{Whakapapa}

My keynote presentation at the New Zealand Association of Psychotherapists (NZAP) 2016 conference explored how Papatūānuku (mother earth) and her progeny connect with the philosophies of romiromi Māori healing. It explained how our tohunga (priests/priestesses in Māori healing) link into nature as a resource for healing. The whakapapa (genealogical links) slides in my presentation validated and personified my tribal descent to the spiritual phenomena of nature, many of whom are identified as both tangible (living) and intangible (non-living spiritual phenomena) guardians in Māori culture.

My slides also described Ruamano and his sister Hinekorako who rode alongside the ancestral waka (canoe) Takitimu which carried the expert tohunga and the healing lores of our tribe (Mitchell, 1944). Ruamano is the timeless taniwha (spiritual guardian) of the Wairoa River who can shapeshift into the form of a whale, a dolphin or an eel (Lambert, 1988). Hinekorako is a tipua (phenomena of nature), manifesting as a beautiful rainbow living in Te Reinga on the outskirts of Wairoa (Lambert, 1988). The whakapapa traced back to the parents of Ruamano and Hinekorako, identifying Tangaroa as the personification of the grandfather of the sea and Hinemoana-nui as the grandmother of the ocean. Tracing my whakapapa back to Tangaroa and Hinemoana-nui is relevant to Māori healing because they are a vital part of purepure (spiritual cleansing) ceremonies. The personification of these spiritual phenomena of nature have long been part of Māori mātauranga (knowledge) (Pere as cited in Mildon, 2016).

Whakakapapa is often used in oral Māori literature including waiata (songs), karakia (incantations to nature), takutaku (healing chants to nature), moteatea (chants that tell the local history), whakataukī (proverbs), and pūrākau (stories). The ancient mother energies of nature are often found in these whakapapa and, as these energies relate to unconditional familial love, they are very important to the holistic wellbeing of whānau (family) Māori (Pere as cited in Mildon, 2012).

My doctoral research (Mildon, 2016) showed positive effects on whānau ora (family wellbeing) when the kaitiakitanga (guardianship) of the mother energies was regularly introduced into everyday family life. In addition, I found that normalising these mother energies was essential to the transmission of healing knowledge and was instrumental in the kaitiakitanga of our natural environment. In turn, the tamariki (children) in these healthy whānau can role model kaitiakitanga and transmit the knowledge to their own children as has been the Māori way since the beginnings of time. Validation of kaitiakitanga for me as a keynote speaker was when a fantail flew into the lecture room at the end of my presentation and hovered above me. It was a moving experience that resulted in tears of joy and was a timely reminder of my whakapapa as a wahine (woman) to the bird family.

\section{Whānaungatanga}

The fantail is one of the progeny of Papatūānuku just as we are. Māori identify themselves as tangata whenua (people of the land) so claim descent to Papatūānuku and her progeny. 
Manu Korewha once shared the whakapapa of the wahine to the bird whānau as taught to him by his elders as a koha (gift) to me. The late Awhina Riwaka, Tohunga rongoā from Wellington, has quoted our human whakapapa, as taught to her by her mother, back to the marriage of Tane (God of the forest) with the feminine lines of the trees. The holistic view of tangata whenua and our connections with nature is defined in the Mâori culture as whānaungatanga. The underpinning value at the core of whānaungatanga is aroha (unconditional love) (Spiller, Erakovic, Henare, \& Pio, 2011). From a Māori worldview, the philosophy of oneness with all connects Māori with mother earth and all her progeny:

Ko au ko Papatūānuku, ko Papatūānuku au.

I am mother earth and mother earth is me.

Ko au te awa, ko te awa au.

I am the river and the river is me.

Ko au ko Hine-nui-te-ra, ko Hine-nui-te-ra au.

I am the ancestress of the sun and the ancestress of the sun is me.

This wider concept of whānaungatanga (family togetherness) therefore extends way beyond the contemporary concept of the nuclear family with links to Papatūanuku (earth mother), Hine-nui-te-po (ancestress of darkness), Hinemarama (ancestress of the moon), Hine-nuite-ra (ancestress of the sun), and Hine-te-iwaiwa (ancestress of the stars). These divine feminine epistemologies position the ancient mother energies as the foundation of Màori healing, a socially constructed phenomenon, laden with timeless cultural, spiritual, and social rituals.

\section{Atua Māori}

The Māori epistemological worldview of atua (divine beings including male gods and the female goddess) describes spiritual metaphors that further define the relationship between people and their natural world. Evans (1994) asserted that the divine feminine exists in our understanding of the landscapes, the mountains, the seas, the rivers, the stars, the moon, the darkness, the forest, the mist, and the rainbows. These are all linked to us and link us as one whānau.

Ko au, ko Hine-pu-kohu-rangi, ko Hine-pu-kohu-rangi.

I am the mother of the mist and the mother of the mist is me.

Ko au, ko Hinekorako, ko Hinekorako au.

I am the ancestress of the rainbow and the ancestress of the rainbow is me.

Ko au, ko Tawhirimatea, ko Tawhirimatea au.

I am the guardian of the winds and the guardian of the winds is me.

Ko au, ko Hinemoana-nui, ko Hinemoana-nui au.

I am the grandmother of the sea and the grandmother of the sea is me.

Ko au, ko Ruamano, ko Ruamano au.

I am the spiritual guardian whale and the spiritual guardian whale is me. 
My doctoral research showed how the philosophy of romiromi Mãori healing relates to our connection with the natural environment in which we live. Dr Rose Pere described this connection as the oneness concept whereby we are one with everything that exists in the universe. He atua. He Tangata. We are both magnificently divine and beautifully human (as cited in Mildon, 2012).

In terms of spiritual interconnectedness, Dr Pere explained how we are a spirit having a human experience on earth (as cited in Mildon, 2012).

Mãori are not joined to the land; they are an integral part of nature, with a relationship to every other living thing, defined by whakapapa ... as guardians of nature ... key to the health of both individual species and whole ecosystems. (Williams as cited in Ka'a, Moorfield, Reilly, \& Mosley, 2004, p. 50)

Nurturing Papatūānuku is key to sustaining the spiritual healing tools of nature. For Mãori, healing Papatūānuku and the water that surrounds her likewise involves healing and nurturing ourselves as humans. So, in caring for mother earth and her progeny, we in turn heal ourselves. The concept of Māori healing therefore supports the ancient Indigenous philosophy that when we learn to heal ourselves, we also heal mother earth.

\section{The Metaphysical Concept Of Oneness}

Traditional Māori healing rituals and practices are essentially based on the metaphysical Māori concept of oneness with everything that exists. The tohunga are experts in diagnosing unexplainable spiritual imbalances and so use many spiritual tools that link them with the universal resources. The practices and rituals of each individual tohunga is unique to their whakapapa and related to the spiritual phenomena of regional landscapes or waters that are unique and culturally diverse. Some tohunga will use karakia (incantations to spiritual phenomena), rongoā Māori (natural medicines made from plants, bark, and leaves), purepure (cleansing ceremonies in the sea, rivers or mountains), mirimiri (manipulation of spiritual energies), taa miri (intuitive diagnosis), romiromi (release of energy) using all of the above, greenstone, wood, and deep bodywork to open haemata (master points) in the body, and takutaku (chants to natural phenomena) as healing tools.

Takutaku is an important ritual used in romiromi healing because it involves ancient chants that incite the powers of some of these spiritual phenomena or tribal ancestors, many of which descend from the ancient mother energies. Manu Korewha sang a takutaku (chant) before my presentation at the NZAP conference to incite some of the old mother energies. The main purpose of this traditional ritual was to clear the energy in the room to set the scene for my presentation. A number of conference attendees were unable to explain why or how they were moved so deeply by the takutaku. Some expressed how they had experienced wells of emotion during the takutaku while others struggled to make sense of tears running down their faces. Although healing may be interpreted differently by each of us, it is my experience that tears of joy are a powerful source of healing and are validation of the presence of the ancient mother energies of unconditional love.

The hongihongi ritual at the powhiri (traditional welcoming process) was one of my 
most memorable joys of the NZAP conference. The sharing of the breath nose to nose, forehead to forehead, heart to heart, and spirit to spirit with each person, gave me an opportunity to connect with some of the deeply spiritual healing practitioners present, each with their own culture, worldview, and expertise. It also enabled me to see how so many of you have supported others through some of their darkest moments. With an understanding that so many practitioners were working with whai-ora Māori (Māori clients/patients), it was an honour to reciprocate by sharing some of the Mãori healing philosophies.

Purepure is an ancient Māori healing ceremony that is held in the sea or on the mountains. It is used by tohunga as a spiritual clearing process using spiritual energy and takutaku. The purepure ceremony enables people to release old emotional experiences held in the waters of the body. I feel very privileged to have experienced some of these traditional purepure ceremonies that incite the taniwha (spiritual guardians) and the tipua (natural phenomena) specific to the tribal regions to share their healing energies and bring about a spiritual cleansing for the people, the land, and the waters in that community. Tangaroa and Hinemoana-nui are two of the most powerful healing conductors so, as students of the late Papa De La Mere, we were expected to soak our bodies in the sea for hours at a time, be it winter, summer, autumn or spring. Using the energies of the atua of the sea, the takutaku used for purepure is used to neutralise the body of ngangara (negative energies/entities) trapped in the mind, body, spirit, and whakapapa lines.

\section{Working With Whai-ora Māori}

In my own experience of working with whai-ora Mãori, dreams, visions, intuition, prophecy, and revelations are often an integral part of their healing journey. Whai-ora share these experiences or spiritual awarenesses quite openly during healing sessions because they are a reality in their everyday lives. When whai-ora experience spiritual imbalances however, these spiritual experiences can turn into a nightmare, especially if they do not have the right spiritual mentors to guide them. If the whai-ora is fearful of the unknown and is using alcohol on top of prescribed medication, such spiritual imbalances can become very traumatic.

Dr Rose Pere contrasted the tohunga of the hē and the tohunga of the hā. The tohunga of the hè creates a dependence so that the whai-ora cannot assess their own wellbeing and have to go backwards and forward to the tohunga for advice. The tohunga of the hà however, empowers the whai-ora to be more spiritually aware and encourages them to trust in their own intuitive wisdom, supporting them to find their own solutions (Pere as cited in Mildon, 2012). I sometimes share my own experiences of being mentored by tohunga to support whai-ora to understand the context of their own spiritual experiences. I also venture out into the bush with whai-ora so they can literally experience using all the senses, silencing the mindless chatter of the mind to experience the rongoā healing of mother earth through listening to the plants, the insects, the birds, the waters, and the trees.

Using a reciprocal approach to healing can also support whai-ora to realise that they have the power to heal and be healed. Knowing that our feet are our power source, when we place our feet on Papatuānuku, more especially in the dew, we not only heal ourselves but heal mother earth at the same time. Taking responsibility for healing and being healed by being 
one with mother earth can support whai-ora in releasing and neutralising the toxic emotions that can rob them of tranquillity and peace of mind. Using the energies of Papatūānuku like this can help to draw out ngangara (negative energies) and re-energise our being, resulting in the reciprocity of spiritual wellbeing.

Ko au, ko Papatūānuku, ko Papatūānuku au.

I am mother earth and mother earth is me.

Ngangara can be likened to negative thoughts that we have given birth to and then feed with emotions like fear, doubt, anger, hatred, and jealousy. Often ngangara are deep-seated painful emotions residing in the puku riri, lower abdomen. This expertise of the tohunga romiromi is instrumental in working with the whai-ora to diagnose the spiritual core of the puku riri which in turn can release the hold of the ngangara. Hinemoana-nui, our ancestress of the sea, is also instrumental in drawing out these negative energies from the feet. Bathing the body in her waves can also neutralise the tapu (sacredness) of ngangara and re-balance the whai-ora in a holistic sense, making the body, mind, and spirit noa (normal) again.

In these contemporary times, the te reo Mâori (language) taught in classrooms tends to focus on rules and grammar. In contrast, the old Te Reo is very poetic and symbolic with a depth, width, and breadth of meanings pointing towards metaphysical realities. Authentic tohunga share the ancient philosophy of te reo Māori as the voices of nature used for healing purposes. The epistemologies of the ancient mother energies link with these voices of nature. Whannau ora is also connected with the philosophy of these voices of nature that are used in romiromi Māori healing.

In providing a brief introduction of the spiritual philosophies of Māori ways of being and Māori healing, I hope that practitioners might consider working with Māori a little differently. Perhaps we may remember who we really are and remember what we came here to do in this lifetime on earth so that we can collectively make a difference for future generations. May we be intentional, authentic, and reciprocal in our healing work so that this energy will ripple out to our grandchildren who will care for the landscapes and waters of our mother earth and all her progeny. Mauri Ora tātou. May we all attain the life force of wellness.

\section{References}

Evans, R. (1994). The negation of powerlessness: Māori feminism, a perspective. Aotearoa/New Zealand [Special Issue] Hecate, 20(2), 53-65.

Ka'ai, T., Moorfield, J., Reilly, M., \& Mosley, S. (Eds.).(2004). Ki te whaiao: An introduction to Māori culture and society. Auckland, Aotearoa New Zealand: Pearson Education.

Lambert, T. (1988). The story of old Wairoa and the East Coast district, North Island, New Zealand, or, past, present, and future: A record of over fifty years progress. Wellington, Aotearoa New Zealand: Reed.

Mildon, C. (2012). The essentialism of the Tohuna. Unpublished thesis in the Masters of Indigenous Studies. Whakatāne. Aotearoa New Zealand: Te Whare Wānanga o Awanuiārangi.

Mildon, C. (2016). Romiromi: Traditional forms of Indigenous Māori healing. Unpublished doctoral 


\section{Charlotte Mildon}

thesis in the Doctorate of Philosophy. Whakatāne, Aotearoa New Zealand: Te Whare Wānanga o Awanuiārangi.

Mitchell, T. (1944). Takitimu: A history of Ngāti Kahungunu. Wellington, Aotearoa New Zealand: A.H. \& A.W Reed.

Spiller, C., Pio, E., Erakovic, L., Henare, M. (2011). Wise up: Creating organizational wisdom through an ethic of Kaitiakitanga. Journal of Business Ethics, 104(2), 223-235. doi: 10.1007/ s10551-011-0905-y

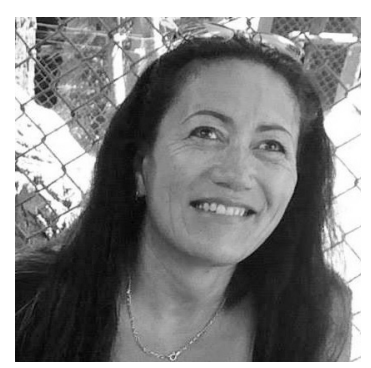

Charlotte Mildon has worked for over 20 years in various forms of cultural bodywork healing, the last decade or so as a contemporary practitioner of traditional $\mathrm{Te}$ Oomai Reia romiromi Māori healing. She specialises in the intuitive diagnosis of spiritual, physical, emotional, mental, and generational trauma. Charlotte uses traditional Māori takutaku and romiromi bodywork to support the releasing of spiritual entities and the clearing of unwanted energies in the cellular memory of the body. Her doctorate research explored the interconnectedness of the ancient mother epistemologies of nature and Indigenous forms of traditional Māori healing romiromi. Charlotte offers cultural supervision, group professional development, Indigenous research, and facilitates community romiromi wānanga. Contact details: tohungatanga@xtra.co.nz . 